\title{
Application of Component Acoustic to Identify The Sound Wave of Sundanese
}

\author{
Siti Maryamah ${ }^{1 *}$, Suryatno Wiganepdo ${ }^{2}$ \\ \{ $\underline{\text { smaryamah68@gmail.com }}$, suryatno.wiganepdo@email.unikom.ac.id $\}$ \\ ${ }^{1}$ Departemen Bahasa dan Sastra Inggris, Universitas Komputer Indonesia, Indonesia ${ }^{2}$ Departemen \\ Manajemen, Universitas Komputer Indonesia, Indonesia
}

\begin{abstract}
The purpose of this research is to measure the frequency of human sound waves with presented data in Praat software through acoustic-phonetic approximation to identify if the speaker can pronounce the word well. The writer is focused on Sundanese as a speaker. Praat provides many benefits for people in knowing information about the existing frequency, duration, and intonation of sound that is spoken by the speaker. Besides, this software can identify extraordinary sounds like bat sounds. The sound of a bat has a $20.000 \mathrm{hz}$ frequency that is unable to be heard by human ears. Through Praat, the frequency can be identified. The method used in research is observation by collecting the speaker's recording. The result of this discussion is to identify components of acoustic-phonetic which are frequency, duration, and intonation. The conclusion is that Praat will provide support for Sundanese speakers to say English words that are conducted of consonants.
\end{abstract}

Keywords: Acoustic, Sound Wave, Speech Therapy

\section{Introduction}

Every child has the right to grow well, but mute children have special needs in their growth. Sadly, mute sufferers are increasing in numbers every year. One way to handle the delay in talking is by carrying out a speech therapy program [1]. However, there is still no known cause of mute [2] and the aspect of communication will be interrupted and the messages of communication cannot be delivered maximally [3]. Education to mute people still has not reached maximum yet and it is proven by the lack amount of counseling for parents whose children have special needs. Although, several therapies have been applied to help them in speaking normally and the example is speech therapy which can also be analyzed by acousticphonetic approach.

Phonetics is a part of phonology that studies produced vowels, consonants, and the organ of sounds which has its characteristics structure in every language. Vowels are divided into three things that affect the quality of sounds which are controlled by the shape of the lips and the forwardness, backwardness, elevation, and depression of the tongue. Based on the vocal cords. The consonants are divided into voiceless and silent voices. The quality of the consonants is divided into 3 parts. First, the presence of vibrations in the vocal cords. Second, the consonant's articulation which is divided into bilabial, labiodental, dental, alveolar, palatal, velar, glottal, and laryngeal. Third, the consonants are divided into fixed consonants, sliding, side, vibrating, nasal, and semivocal based on the articulation [4]. 
According to O'Grady, Articulatory phonetics explains the produced sound and divided into 3 parts. First, the identification of the location and vibration of the tongue and lips. Second, the description and visualization of sound wave frequency that refers to acoustic phonetic. The last is auditory phonetic that is accepted sound by the respondent [5]. Based on Fonetik Akustik book, acoustic phonetics is a discipline of study that combines 3 branches of knowledge which are engineering (electro), linguistic (phonetic), and psychology (cognitive) [6]. Phonetic acoustic describes how the sound is produced and responded by the mechanism of the speaker and how the sound movement in the air stimulates the hearing process. Phonetic acoustic is divided into 3 parts: frequency, duration, and intonation which by using Praat software sound wave can be visualized. This software showing the visualization of sound wave frequency and acoustic phonetic components.

This paper aims to help speech therapy by visualizing the frequency and component of acoustic phonetic that is spoken by the speaker. The method used in this research is observation by collecting the recordings of the speaker.

\section{Method}

The methods used in this research are descriptive analysis and collection method which was conducted through the recordings of two mute women and men in Sekeloa. Then they read 16 (sixteen) English words presented in Table 1:

Tabel 1. Data

\begin{tabular}{cc}
\hline & Data \\
Before & Formula \\
Father & For \\
Wife & Fulfill \\
Of & Life \\
Selfish & Fake \\
Fishing & Facial \\
Found & Foam \\
Fish & \\
\hline
\end{tabular}

The results of the recordings are embedded in the Praat application. In this application, all of the words are produced, however, it is only fricative consonant [f] sound waves that are analyzed in spectrogram. The speech analyzer can visualize and measure the acoustic components of speech sounds. 


\section{Results and Discussion}

\subsection{Visualization of Sound Wave in Spectrograph}

The tools used to assess the sound waves of language and measure the air movement include spectrograph (a tool for exposing and analyzing frequencies and pressures), and oscilloscope (tools for describing the characteristics of sound loudness) [7]. The spectrograph is to show the frequency vs. time and duration. Figure 1 is the example of a sound wave in spectrograph:

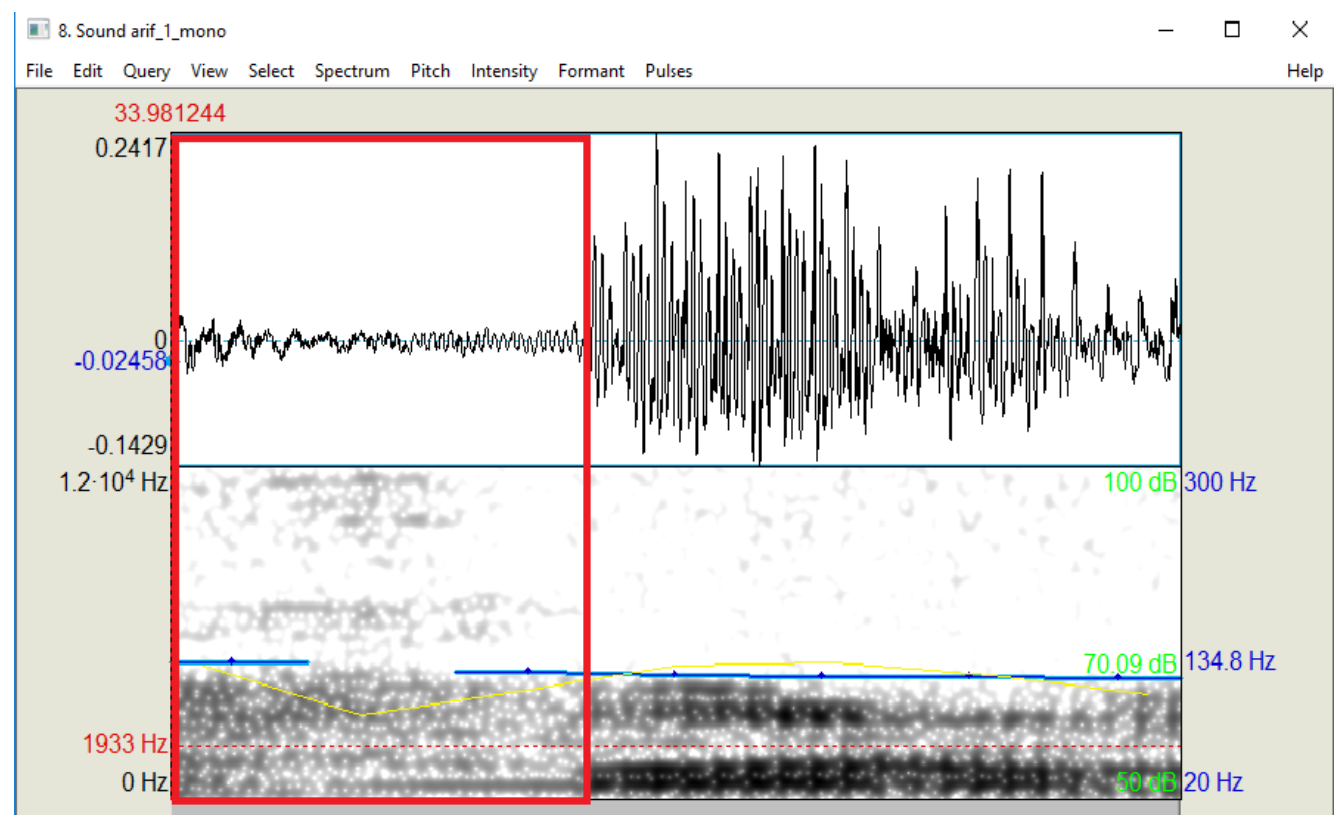

Figure 1. The sound wave of spectograph.

The Spectrogram is a short time-frequency analysis with the horizontal axis is in the form of a time function while the vertical axis is in the form of frequency function. By performing a spectrogram analysis, it can be seen that the frequency changes as a function time and the frequency component in a signal can be seen [8]. As of figure 1, marked red box is sound wave energy. The darker the waves, the more energy received. The acoustic-phonetic component also shown in the spectrograph where the frequency is marked with $\mathrm{Hz}$ units, while intonation is indicated by $\mathrm{dB}$ and duration is marked with units /s. Every individual has their own sound characteristic but the structure of sound wave energy is the same. In figure 2.1.1, the sound wave of the speaker is normal.

\subsection{The Components of Acoustic Phonetics}

Phonetics is a scientific study that examines how humans produce speech sounds and the sound waves of language, and also how human hearing devices can accept the sounds of language which is going to be analyzed by the human brain. In general, phonetics can be divided into three fields of study, namely physiological phonetics, 
acoustic phonetics, and auditory phonetics [9]. Based on the component, acoustic phonetic has 3 characteristic components which are frequency, duration, and intensity.

\subsubsection{Frequency}

Table 2 is showing the frequency of the speaker. Frequency is divided into highest frequency, lowest frequency, and central frequency. Central frequency is the darkest in sound wave.

Table 2. The average frequency of speaker

\begin{tabular}{cccc}
\hline SPEAKER & THE AVERAGE OF & THE AVERAGE OF & THE AVERAGE OF \\
HIGHEST FREQUENCY & LOWEST FREQUENCY & CENTRAL FREQUENCY \\
\hline FIRST SPEAKER & 13112 & 2045 & 3447 \\
SECOND SPEAKER & 13414 & 1740 & 3328 \\
THIRD SPEAKER & 12393 & 1548 & 3243 \\
FORTH SPEAKER & 12973 & 1778 & 3340 \\
\hline
\end{tabular}

As of Table 2, the average highest frequency is not higher than $13.000 \mathrm{~Hz}$, and the lowest is not lesser than 3.000. This nominal is the normal frequency that people usually speak. Whereas the central frequency is not more than 3.500 which means the speaker is not too loud and not too quiet.

\subsubsection{Duration}

In component acoustic phonetic studies, the duration of speaking has an important role. It becomes a measurement of language has a long vowel and a short vowel system, or a long (geminate) and short consonant [10]. The duration of the speaking are shown in Table 3.

Tabel.3 The duration of speaking

\begin{tabular}{cc}
\hline SPEAKER & DURATION \\
\hline FIRST SPEAKER & 0,1065 \\
SECOND SPEAKER & 0,0703 \\
THIRD SPEAKER & 0,1060 \\
FORTH SPEAKER & 0,0942 \\
\hline
\end{tabular}

\subsubsection{Intensity}

The intensity of the speech speakers are shown in table 4 . 
Tabel 4. Intensity of the speaker

\begin{tabular}{cc}
\hline SPEAKER & INTENSITY $(\mathrm{dB})$ \\
\hline FIRST SPEAKER & 64 \\
SECOND SPEAKER & 65 \\
THIRD SPEAKER & 58 \\
FORTH SPEAKER & 62 \\
\hline
\end{tabular}

\section{Conclusion}

Speech therapy is an important thing to assist mute people to be more fluent in pronunciation, especially the English word. Through the Praat application, therapists can measure the frequency and show the visualization of the sound wave. It can help reference the speech sound and can provide easier control of the progression of the patient in the therapy.

\section{References}

[1] Rahayu, S : Evaluasi Pelaksanaan Program Terapi Wicara Dalam Meningkatkan Perkembangan Anak Terlantar Di Yayasan Sayap Ibu Kebayoran Baru, Jakarta Selatan.

[2] Sabri, R., Yeriziel, E., \& Mira, A : Pengaruh Terapi Autis Terhadap Kemajuan Anak Autis Di Sekolah Khusus Autisme Di Kota Padang. (2006)

[3] Prihartono, W : Identifikasi Tuturan Latah: Pendekatan Fonetik Akustik. Madah: Jurnal Bahasa dan Sastra, 8(2), 161-176. (2018)

[4] Sudaryat, Y., Prawirasumantri, A., \& Yudibrata, K. : Tata basa Sunda kiwari. Yrama Widya. (2007)

[5] Putri, D. R. S. : Pelafalan bunyi Frikatif dan Afrikat oleh Mahasiswa Sastra Sunda Angkatan 2010 Universitas Padjadjaran. Students e-Journal, 1(1), 3. (2012).

[6] Irawan, Y., \& Barat, B. B. P. J. Fonetik Akustik sebagai Pendekatan Linguistik. In Seminar Tahunan Linguistik (Setali UPI) (pp. 448-452). (2013).

[7] Hartini, L. : Penerapan Fonetik Akustik Dan Teori Grice Pada Rekaman Penyadapan Telepon Sebagai Alat Bukti Hukum: Kajian Linguistik Forensik Terhadap Percakapan Antara Artalyta Suryani Dengan Jaksa Urip Tri Gunawan. Jurnal Wawasan Yuridika, 23(2), 223-240. (2014).

[8] Suwarno, D. U. : Analisis Frekuensi Sinyal Sirine Menggunakan Spectrogram

[9] B. Pisoni David, : Auditory And Phonetic Memory Codes In The Discrimination Of Consonants And Vowels. Indiana University Bloomington. (1973).

[10]Irawan, Y.: Kontras Intonasi Deklaratif-Interogatif Dalam Bahasa Sunda (Doctoral dissertation, Tesis Universitas Indonesia). (2011). 